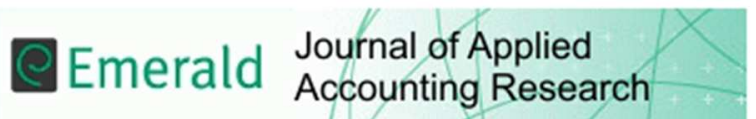

\section{The effect of CEOs' characteristics on forward-looking information}

\begin{tabular}{|r|l|}
\hline Journal: & Journal of Applied Accounting Research \\
\hline Manuscript ID & JAAR-03-2016-0027.R2 \\
\hline Manuscript Type: & Research Paper \\
\hline Keywords: & $\begin{array}{l}\text { Voluntary disclosure, Forward-looking information disclosure, CEOs' } \\
\text { characteristics, Jordan }\end{array}$ \\
\hline \multicolumn{2}{|l}{} \\
\hline
\end{tabular}

SCHOLARONE ${ }^{m}$

Manuscripts 
The Effect of CEOs' Characteristics on Forward-Looking Information

2 


\section{Introduction}

We extend the previous literature on FLI disclosure by investigating the effect of CEOs' characteristics on narrative FLI disclosure. Voluntary disclosure, such as FLI, is considered essential in demonstrating a company's position to shareholders, and other stakeholders in the wider sense of the term (Jensen and Meckling 1976; Lim et al. 2007; Hassanein and Hussainey 2015). In fact, a number of studies argue that the most significant items in voluntary disclosure are FLI (Francis et al. 2008a; Wang and Hussainey 2013). We focused on forward-looking narrative because existing evidence suggests that managers who are willing to manipulate the tone of corporate disclosure are likely to target forward-looking statements for such purposes (Schleicher et al. 2007; Schleicher and Walker 2010). Thus, our study differs from previous studies on FLI disclosure in that we focus exclusively on how the personal characteristics of CEOs affect the voluntary narrative FLI. Previous studies suggest that corporate reporting practices vary predictably, in accordance with the particular individual characteristics of directors (Schrand and Zechman 2012; Davidson et al. 2013), and that these characteristics have an effect on managers' decisions, including their influence on voluntary disclosure strategies (Bamber et al. 2010), accruals quality (Francis et al. 2008a) and accounting policies (Arun et al. 2015).

Disclosure regarding a company's future performance is mostly made on a voluntary basis, subject to managerial discretion (Clarkson et al. 2008). Although previous studies found that FLI disclosure enhances investors' ability to predict future earnings (Hussainey et al. 2003; Hussainey and Walker 2009; Athanasakou and Hussainey 2014), academic research has shown that no study has used the level of FLI disclosure to investigate the relationship between CEO characteristics and voluntary disclosure. This limitation provides the motivation for the present study, by providing evidence on the nature of the relationship between FLI disclosure and CEO characteristics in the context of Jordan. Furthermore, we were motivated by the unique role the CEOs can play in FLI statements, particularly through narrative disclosures.

We define FLI disclosure more widely and include all types of FLI disclosure, including management strategy, valuations of opportunities and risks, forecast data, qualitative and non-forecast data. This sort of approach is useful for the study is based on Jordanian companies, whose forward-looking statements are qualitative in nature and dominated by good news. We used 1,206 annual reports of 201 privatized Jordanian companies listed on the 
ASE over the six-year period, 2008-2013, with the technique of manual content analysis to examine the narrative evidence from the annual financial reports.

It was found that CEO overconfidence and gender have a significant positive association with the level of FLI disclosure, while CEO age is negatively associated with FLI disclosure. The study provides early evidence of the impact of CEO characteristics on the level of FLI disclosure in a developing country. These findings should be of interest to policymakers, regulators and academics regarding the impact of CEO characteristics on the level of FLI not only in Jordan, but also in other developing countries, particularly in the Middle East and North Africa (MENA).

Jordan is significant in the MENA region as a pioneering service-based economy, largely because of its relative scarcity of natural resources. While other economies in the region are characterised by heavy state regulation and massive government bureaucracies (for political reasons, including the disbursal of oil and gas revenues), Jordan has pioneered the market economy and trade liberalization, along with its historic investment in education. Jordan is thus much more aligned to international norms in the globalized economy (Aljifri and Khasharmeh 2006). Over the years, the Jordanian government has worked closely with the IMF, practised careful monetary policy and made significant progress with privatization and a liberalized trade regime (Al-Akra and Ali 2012). The ASE, the biggest stock market in the region, operates an automated order-driven Electronic Trading System and works in close collaboration with the Jordan Securities Commission (JSC) on surveillance matters; it has a strong relationship with other exchanges, associations and international organizations.

The Jordanian capital market is mature by regional standards and is integrated with the Middle East market, which implies little long-run risk diversification (Saadi-Sedik and Petri 2006). The government of Jordan has introduced numerous reforms for accounting regulations, including securities exchange laws and corporate disclosure practices. These reforms contribute to more transparent markets and the listed companies have enhanced their voluntary disclosure (Al-Akra and Ali 2012; JSC 2015). Furthermore, Omar (2007) found that Jordan showed a significant improvement in disclosure after changes in the economic and accounting regulations (see Appendix 1). Thus, Jordan provides a unique national context in which to analyse the impact of CEO traits on the level of FLI disclosure. 
Our paper provides two contributions to the literature in terms of determinants of FLI disclosure. First, it examines the impact of CEOs' personal traits on the level of FLI disclosure. Instead of the current literature's prevailing focus on the determinants of FLI disclosure on institutional characteristics, this study provides evidence of the association between CEO traits and FLI disclosure. Furthermore, only a limited number of studies have examined FLI disclosure in developing countries, and even fewer in MENA. The remainder of this paper organised as follows. Section 2 reviews the related literature and hypotheses, while Section 3 presents the research method. Section 4 presents the study findings, and Section 5 concludes the paper.

\section{Literature Review and Hypotheses}

The disclosure of corporate information can be a signal to capital markets, as expressed in signalling theory, which posits that managers use voluntary disclosure to signal private information to the market (Watts and Zimmerman 1978). The sending of a signal is based on the assumption that it should be favourable to the signaller, such as indicating the higher quality of its products compared with those of competitors (Salama et al. 2010). Furthermore, companies disclose more specific information to investors to signal that they are better than other companies in the market for the purpose of attracting new investment and enhancing their reputation (Campbell 2001). In line with this argument, managers are likely to disclose more FLI to the interest-related parties to increase their confidence about the company's future performance (Singhvi and Desai 1971). In addition, previous studies found that managers in family companies are more likely to disclose more FLI disclosure than those managing non-family companies (Ali et al. 2007; Chau and Gray 2010). Similarly, the current study argues that non-financial Jordanian companies are more likely to disclose more FLI, since a large proportion of Jordanian companies are family controlled. There were 128 (64 percent) family companies and 73 (36 percent) non-family companies listed on the ASE over the period 2008-2013 (ASE 2015). Thus, the context of Jordan provides an opportunity for managers to disclose more FLI. The last decade has seen a growing amount of research on the topic of managerial characteristics of CEOs. It is obvious that the sociological, professional, individual and physiological characteristics of managers may have an effect on various decisions (Bamber et al. 2010; Hirshleifer et al. 2012; Dejong and Ling 2013). Since CEOs are the key decision makers in voluntary FLI disclosure, it is important to investigate 
the relationship between their personal characteristics and FLI disclosure, which remain ambiguous in the current literature.

\subsection{CEO Overconfidence}

The general climate of mistrust in corporate leadership since the 2008 financial crisis has resulted in significant research attention being devoted to the personal attributes of CEOs in recent years, particularly their overconfidence in corporate voluntary disclosure (Schrand and Zechman 2012; Ahmed and Duellman 2013). Langer (1975, 315) defined overconfidence as “an overestimation of one's own abilities and outcomes relating to one's personal situation". Overconfidence as a personal characteristic tends to overestimate the results of one's decisions, and underestimate the risks associated with those decisions. Previous literature suggests that individual overconfidence has two key aspects: miscalibration and overoptimism (Skala 2008; Libby and Rennekamp 2012). Miscalibration is associated with individuals underestimating uncertainty when predicting events (Hribar and Yang 2015).

When individuals assess their relative skill, they tend to overstate their acumen relative to the average (Alicke 1985). This effect can extend to business decision making (Camerer and Lovallo 1999). While this is somewhat related to risk attitudes of individuals, it is also related to self-attribution bias, the tendency to attribute successful results from decisions to one's own actions, and bad outcomes to external factors (Dowling and Aribi 2013). Overoptimism refers to individuals who are unrealistically optimistic about uncertain outcomes. Accordingly, the overconfident individual believes that an uncertain outcome will be better than what would be predicted by an unbiased expectation. Both aspects of overconfidence are likely to be associated with the level of FLI disclosure decisions.

Schrand and Zechman (2012) used a sample of 49 firms subject to the US Securities and Exchange Commission (SEC) and examined the relationship between CEO overconfidence and overstatement of earnings. Their findings suggested that overconfident executives are more likely to exhibit an optimistic bias and thus are more likely to start down a slippery slope of issuing intentional misstatements. Similarly, Ahmed and Duellman (2013) examined the association between CEO overconfidence and accounting conservatism and suggested a negative relationship between CEO overconfidence and accounting conservatism among US firms. Since overconfident CEOs usually overestimate future sales and return on assets, their overconfidence encourages disclosing more information. In the same vein, Hribar and Yang (2015) examined the effect of overconfidence on management forecasting behaviour across 
US firms and found that overconfidence is positively associated with the decision to issue voluntary forecasts, and that their forecasts have a greater optimistic bias. Hence, an overconfident CEO is more likely to favour a high level of FLI disclosure. Based on this discussion, and consistent with the agency theory, family companies expected to disclose more FLI disclosures to reduce the asymmetry information (Minichilli et al. 2010), naturally this would motivate overconfidence CEOs to disclose more FLI and be optimistic about the future of the company. Following this, we expect that Jordanian companies managed by overconfident managers disclose more FLI disclosures.

H1. A positive association exists between CEO overconfidence and the level of FLI disclosure among Jordanian companies.

\subsection{CEO Gender}

Previous literature has documented the existence of difference between males and females in terms of personality, communication style, decision making, risk-taking behaviour, leadership, ethics, expertise and general performance in business (Peterson and Philpot 2007; Dowling and Aribi 2013). The findings of these studies suggest that the gender of company executives has an influence on corporate decisions, and that female executives tend to take a different perspective and demand different information than their male counterparts. However, the extent to which gender influences corporate reporting decision-making differences remains unclear. For example, Ge et al. (2011) found no significant relationship between CFOs' gender and accounting choices, while Krishnan and Parsons (2008) found that gender diversity in senior management affects earnings quality through an increase in the quality of reported earnings. Similarly, Gul et al. (2011) examined whether the gender of directors affects fully independent audit committees' ability to constrain earnings management and thus their effectiveness in overseeing the financial reporting, finding that the proportion of females on the audit committee is not associated with earnings management. Jia et al. (2014) investigated the relationship between the facial structure of CEOs and their companies' financial misreporting, and the results showed that companies with CEOs who have more masculine faces have a higher incidence of financial misreporting. Recent studies by Ho et al. (2015) and Arun et al. (2015) found that female directors tend to adopt more restrained earnings management, reflecting a proclivity toward more conservative accounting policies, and a generally more conservative mind-set among female CEOs characterised by a tendency to be less aggressive and more anxious. Since large proportion of 
Jordanian companies are managed by male CEOs and based on the notion that male is more risk taking than female, we expect that Jordanian companies managed by male CEOs disclose more FLI disclosure.

H2. The level of FLI disclosure is positively associated with the presence of male CEOs among Jordanian companies.

\subsection{CEO Age}

A number of studies have attempted to explain the relationship between CEO age and the decision-making process. For example, Miller and Shamsie (2001) found that older CEOs tend to take faster investment decisions due to their accumulated experience and knowledge. On the other hand, Bertrand and Schoar (2002) showed that older CEOs (from cohorts with earlier year of birth) are more likely to be conservative in making investment decisions. Li et al. (2011) found that younger CEOs are likely to make more prolific investment decisions, since they need to signal their capability to the stakeholders, while Ge et al. (2011) provided evidence that older CEOs are more likely to use conservative accounting choices. Moreover, Bamber et al. (2010) reported that managers born before World War II are more likely to develop conservative disclosure styles than managers born afterwards. Lin et al. (2014) found a negative significant relationship between $\mathrm{CEO}$ age and internal control quality among 4,374 non-financial US companies. There is no evidence so far on the relationship between the CEO age and the level of FLI dosclosure. This discussion is consistent with the notion that younger managers are more inclined to be information processors and optimistic about the future (Taylor 1975), we expect that Jordanian companies managing with younger managers are more likely to disclose the more FLI disclosure.

H3. The level of FLI disclosure is negatively associated with CEOs' age among Jordanian companies.

\section{Data and Methodology}

Our initial sample for the study is all 270 companies listed on the ASE. However, we excluded all financial companies $(n=42)$ from the initial sample, due to their unique characteristics and the specific regulations and disclosure requirements, which may have an impact on the results (Al-Akra and Hutchinson 2013; Athanasakou and Hussainey 2014; Hassanein and Hussainey 2015). In addition, industrial sectors comprising fewer than six 
firms and companies with missing data were removed from the initial sample (Athanasakou et al. 2009). Thus, the final sample consisted of 1,206 firm-year observations over the study period 2008-2013, as presented in Table 1. This study adopted a six-year period from 2008 to 2013, since the financial crisis started in 2008 and triggered different reforms and corporate governance practices in the same year in Jordan (and indeed worldwide). The data on FLI disclosure was collected from annual reports, each of which was scanned manually. The data on CEOs' characteristics was collected from different sources: annual reports, press releases, and direct communication with analysts. Furthermore, to cover some missing financial information in the annual reports, databases available via the websites of the Securities Depository Centre, the ASE and OSIRIS were used.

\section{Insert Table 1 about sample description}

\subsection{Measuring the Level of FLI Disclosure}

Content analysis, which has been extensively used in previous literature as a powerful tool to explore corporate disclosures (Hussainey et al. 2003; Aribi and Gao 2010; Menicucci 2013; Hassanein and Hussainey 2015), was utilized to gather and explore the items of FLI in the sample of this study. In content analysis, the selection of recording units such as sentences, words, lines, groups of words, pages, paragraphs or whole documents is necessary. This research uses words as a recording unit, since words are considered more reliable as a unit of analysis compared to longer alternatives (Hackston and Milne 1996; Al-Najjar and Abed 2014). Furthermore, $\mathrm{Ng}$ (1985) argued that using sentences, lines, portion of pages and whole documents may be inappropriate because column, print and page sizes may differ from one annual report to another. Thus, to overcome these problems the current study used number of words.

A keyword search was used to identify FLI items within voluntary section in each annual report. The study used a list of 35 forward-keywords established by Hussainey et al. (2003), such as anticipate, next period, coming period, next etc. (see Appendix 2). To allow content analysis to be used in a replicable manner, a checklist instrument with four categories describing the criteria for identifying disclosure as FLI was used in line with previous studies (Barako et al. 2006; Maali et al. 2006). Regarding the disclosure categories, Wallace and 
Naser (1996) and Francis et al. (2008b) reported that there is no consensus or general theory about categories to be selected for examining the extent of disclosure. The selection could be based on reviewing the literature or inspecting the content of FLI (Bryan 1997; Barako et al. 2006).

The categories and the list of FLI items included both financial and non-financial information disclosed by listed firms that may relate to FLI culminated in the generation of four categories and 45 items. Since the focus of this study is FLI, the preliminary four catagories and list of 45 items were sent to various individuals chosen on the basis of their expertise and knowledge of accounting practices (academicians and accounting professionals). Based on valuable recommendations provided by them, the four categories of FLI were confirmed, but the initial list of 45 items was reduced to 28 items by clustering similar items into single ones. This method is consistent with previous literature (Barako et al. 2006; O'Sullivan et al. 2008; Menicucci 2013) (Appendix 3).

Three steps were employed to ensure the reliability and validity of the content analysis process: (1) we developed a set of specified and explicit coding instruments to minimize discrepancies and ensure objectivity; (2) five annual reports were tested by several coders to ensure that all coders adopted the same coding procedures, to resolve any differences between codes; and (3) the coding rules for classification of categories and checklist items were re-confirmed by five different professional accountants, and the results compared to identify possible disagreements.

Besides using the content analysis method, disclosure index was used to measure the extent of FLI. Cerf (1961) was the first study to employ disclosure index to assess the degree of corporate disclosure. Since the 1960s many researchers have extensively used disclosure index to measure the amount of information disclosed in annual financial reports (Maali et al. 2006; Mathuva 2012; Athanasakou and Hussainey 2014). Our approach to scoring FLI items is dichotomous in that each FLI item scores a value of 1 if disclosed, otherwise 0 ; and the approach to scoring is equally weighted. The disclosure index was constructed as a ratio obtained by dividing the number of FLI items disclosed by the total number of FLI for each company (e.g. Cerf 1961; Rizk et al. 2008).

This study used the following disclosure index to measure the level of FLI:

$$
\mathrm{FWD}=\Sigma d i
$$


Where FWD refers to the forward-looking category disclosed, and $d i=1$ if the category contains forward-looking items and zero if not.

The FLI disclosure for each company is set as:

\section{FWD/TDS}

Where TDS is the maximum disclosure provided by the companies in their published annual financial reports.

\subsection{Independent Variables}

Three measures of overconfidence were used, the first of which focuses on option-holding behaviour and stock purchases. Following Malmendier and Tate (2008), we consider overconfidence as a reflection of the degree to which CEOs fail to minimize the degree to which their personal wealth is exposed to company-specific risk. Their measurement is based on the tendency of CEOs to purchase extra stock in their own company despite their own personal wealth, rendering them exposed to company risk at a high level. In buying more company stocks, CEOs expose themselves to higher levels of company risk by overestimating the prospective returns on their own projects in the belief that company stock price would rise more under their leadership than would normally be expected. If CEOs have such overconfident beliefs, they tend to buy up stock in the company in the hope of profiting from the expected future gains. Thus, we defined CEOs as overconfident based on the 'Net Buyer' Measure (i.e. based on whether they were net buyers of the stock of their own companies in the initial six years of the sample). It ought to be noted that in detecting overconfidence in CEOs, they are defined as being overconfident for all the relevant years. A dummy variable was established with 1 representing overconfident and 0 referring to otherwise.

The second measurement of CEO overconfidence is based on CEO investment decisions. Previous studies document that companies' investment decisions are associated with managerial overconfidence (Malmendier and Tate 2008; Campbell et al. 2011), and that overconfident CEOs are more likely to overinvest in capital projects (Malmendier and Tate 2005a; Ben-David et al. 2010). Following Campbell et al. (2011) and Ahmed and Duellman (2013), we measured CEO overconfidence as a dummy variable which takes the value of 1 if the company's capital expenditure scaled by lagged total assets in a given year is higher than 
the median level of companies' expenditures scaled by lagged total assets for the industry type in the same year, otherwise it takes the value 0.

The third measurement of $\mathrm{CEO}$ confidence is based on financing decisions and capital structure. Overconfidence can significantly influence debt/equity choices, and overconfident CEOs will choose to issue more debt than their rational peers do, because of a belief that the firm is less likely to experience financial distress than it actually does (Hackbarth 2008). In Fairchild's (2005) asymmetric information model, overconfidence ultimately leads to excessive use of debt (Minggui et al. 2006; Oliver and Mefteh 2010). In the same vein, Malmendier et al. (2007) indicated that overconfident managers use a higher level of debt than rational managers, thus they underestimate the expected cost of bankruptcy and take on more debt to exploit its tax benefits. We used the leverage ratio as a third proxy for overconfidence.

The CEO gender is measured as a dummy variable with the value of 1 if the CEO is male and 0 otherwise (Skalpe 2007; Yu et al. 2010). The study measures the CEO age as the difference between date of birth and the years of the study period (Cornett et al. 2009; Lin et al. 2014). In addition to these dependent and independent variables, a number of control variables were used to control for the possible effect of a company's characteristics and corporate governance factors that may affect the extent of FLI disclosure (Athanasakou and Hussainey 2014; Sartawi et al. 2014; Hassanein and Hussainey 2015).

\subsection{Model Specification}

The study uses panel regression data to examine the relationship between the level of FLI disclosure and a CEO characteristics. The main regression model used is given by:

$$
\mathrm{Y}_{\mathrm{it}}=\beta+\mathrm{b} \mathrm{X}_{\mathrm{it}}+\varepsilon_{\mathrm{it}}
$$

Where

$\mathrm{Y}=$ Dependent variable (FLI), $\mathrm{X}=$ Independent and control variables (COVER, CAPEXP, FLEVER, CGEN, CAGE, FSIZE, FPROF, FINDU, FDIVID, BSIZE, BDUAL, BMEET, BINDEP, MOWNE, FOWNE, INSTIT, BLOCL), $\beta+b=$ coefficients, $i$ and $t=$ crosssectional and time series dimensions, and $\mathcal{E}=$ error term.

Three models are defined as follows: 
1. FLI $_{\text {it }}=\beta_{0}+\beta_{1}$ COVER $_{\text {it }}+\beta_{2} \mathrm{CGEN}_{\mathrm{it}}+\beta_{3} \mathrm{CAGE}_{\mathrm{it}}+\beta_{4} \mathrm{FSIZE}_{\mathrm{it}}+\beta_{5} \mathrm{FPROF}_{\mathrm{it}}+\beta$

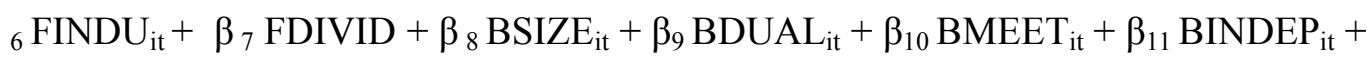
$\beta_{12} \mathrm{MOWNE}_{\mathrm{it}}+\beta_{13} \mathrm{FOWNE}_{\mathrm{it}}+\beta_{14} \mathrm{INSTIT}_{\mathrm{it}}+\beta_{15} \mathrm{BLOCK}_{\mathrm{it}}+\boldsymbol{z}_{\mathrm{I}}$

2. $\mathrm{FLI}_{\mathrm{it}}=\beta_{0}+\beta_{1} \mathrm{CAPEXP}_{\mathrm{it}}+\beta_{2} \mathrm{CGEN}_{\mathrm{it}}+\beta_{3} \mathrm{CAGE}_{\mathrm{it}}+\beta_{4} \mathrm{FSIZE}_{\mathrm{it}}+\beta_{5} \mathrm{FPROF}_{\mathrm{it}}+\beta$ ${ }_{6}$ FINDU $_{\text {it }}+\beta$ X $_{7}$ FDIVID $+\beta_{8}$ BSIZE $_{i t}+\beta_{9}$ BDUAL $_{\text {it }}+\beta_{10}$ BMEET $_{\text {it }}+\beta_{11}$ BINDEP $_{\text {it }}$ $+\beta_{12}$ MOWNE $_{i t}+\beta_{13}$ FOWNE $_{i t}+\beta_{14}$ INSTIT $_{\text {it }}+\beta_{15}$ BLOCK $_{i t}+\boldsymbol{s}_{\mathrm{I}}$

3. FLI $_{\text {it }}=\beta_{0}+\beta_{1}$ LEVER $_{\text {it }}+\beta_{2}$ CGEN $_{\text {it }}+\beta_{3} \mathrm{CAGE}_{\mathrm{t}}+\beta_{4} \mathrm{FSIZE}_{\mathrm{it}}+\beta_{5} \mathrm{FPROF}_{\mathrm{it}}+\beta_{6}$ FINDU $_{i t}+\beta X_{7}$ FDIVID $\beta_{8}$ BSIZE $_{i t}+\beta_{9}$ BDUAL $_{i t}+\beta_{10}$ BMEET $_{i t}+\beta_{11}$ BINDEP $_{i t}+$ $\beta_{12}$ MOWNE $_{i t}+\beta_{13}$ FOWNE $_{i t}+\beta_{14}$ INSTIT $_{i t}+\beta_{15}$ BLOCK $_{i t}+\varepsilon_{\mathrm{I}}$

Where:

$\mathrm{FLI}_{\mathrm{it}}=$ forward-looking disclosure index of company $\mathrm{i}$ in the year $\mathrm{t}$, expressed as \% total FLI disclosed out of all items. COVER = CEO overconfidence, the proportion of CEO share ownership, options, and stock exercise, measured using 'Net Buyer'. CAPEXP = capital expenditures used as an alternative proxy for CEO overconfidence; this is a dummy variable taking the value 1 if the capital expenditure scaled by lagged total assets in year $t$ is greater that the median level of capital expenditures to lagged total assets for the firm's industry in that year. FLEVER = leverage ratio, used as another proxy for CEO overconfidence and measured by total long-term debt divided by total assets. CAGE $=$ CEO age, measured by the difference between the CEO date of birth and years of the study period. CGEN = CEO gender, 1 if male and 0 if female. FSIZE = firm size, natural log of firm's total assets. FPROF $=$ profitability, measured by ROA (net income before tax divided be total assets). FINDU = industry type, from the ISIN, as stated by the Jordanian Securities Depository Centre (each company has a unique 10-digit number). FDIVID = dividends ratio measured as cash dividends divided by net income for the same period. BSIZE = board size, measured by the total numbers of the board. BDUAL = board duality, a dummy variable that takes the value of one if the CEO and chairperson are the same person and zero if otherwise. BMEET = board meeting, the number of meetings per year held by the board of directors. BINDEP = board independence, measured by the total number of outside directors. MOWNE = managerial ownership, measured by the percentage of total shares held by executive directors divided by the total number of shares. FOWNE = family ownership, measured by the proportion of total shares owned by the family; a dummy variable would take one if a family or an individual holds $10 \%$ or more of equity, and the value zero if otherwise. INSTIT = 
institutional ownership, measured by dummy variable which would take one if any institutional held shares, and zero if otherwise. BLOCK = block-holders ownership, measured by a dummy variable that takes the value of one if the firm has an external stockholder owning $5 \%$ or more of the outstanding shares, and the value of zero if otherwise. $\beta=$ the constant. $E=$ residual error.

\section{Results and Discussion}

Table 2 shows key descriptive statistics for all variables used in the study. The minimum value of the FLI disclosure rate is $0 \%$ and the maximum is $78 \%$, which indicates a considerable dispersion in the rates. The mean value of $31.6 \%$ shows a low level of FLI disclosure across the companies. We used the median value $33 \%$ as a benchmark to classify the cutoff between high and low levels of FLI disclosure. In addition, Table 2 shows that $43 \%, 49 \%$ and $29 \%$ of CEOs were overconfident about their company's performance based on 'Net Buyer', capital expenditure and leverage ratio, respectively. The descriptive result shows that $95 \%$ of the CEOs are males. The mean age is 51.11 with minimum and maximum 26 and 84 respectively, and the median value 51 . The median age is used as a cutoff point to classify older and younger CEOs.

The company size value indicates that the companies are widely dispersed. Profitability varies between a minimum value $-85.90 \%$ (loss) and 95\% (maximum profit), with standard deviation equal to $12.53 \%$. The mean value of industry type indicates that $36 \%$ of the sample companies operate in the industrial sectors. Table 2 also shows that the mean value of dividend ratio is $17.6 \%$, with minimum and maximum values of 0 and $97.5 \%$, respectively and correspondingly the median value is 0 with a standard deviation of $29.9 \%$. Concerning the other control variables, board size has a mean value 8.011 , which is consistent with other studies (Peasnell et al. 2005; Sartawi et al. 2014). A dummy variable of board duality has a mean of $20.5 \%$. This figure is lower than the average reported by Chau and Gray (2010), who found that the mean value among Hong Kong listed companies is 54\%. Numbers of meeting and board independence have mean values of 7.572 and 2.020 respectively. Concerning ownership structure, managerial and family ownership have $35.5 \%$ and $61.2 \%$ mean values respectively, while institutions and blockholders are $35.5 \%$ and $48.92 \%$. 


\section{Insert Table 2 about Descriptive Statistics here}

Following descriptive analysis of the variables, Table 3 shows the correlation coefficients between the independent and control variables of the period 2008-2013. The correlation matrix shows that the highest correlation is between board independence and board size, with a coefficient of $41.50 \%$. Table 3 also indicates that no Pearson's coefficient is more that $80 \%$, so there is no multicollinearity problem among the independent variables (Gujarati 2008).

\section{Insert Table 3 about Correlation Matrix her}


Table 4 reports the results of random-effect panel regression. The estimates are presented in three panels: panel A reports the results for the regressions where overconfidence is measured using the 'Net Buyer' method, and panels B and C represent the overconfidence variable based on capital expenditures and leverage ratio respectively. The combination of the independent variables shows respectively $25.69 \%, 38.3 \%$ and $23.45 \%$ of the variation of the dependent variable. The P-Value is highly significant at the level $(F=12.05, p>.00)$, implying that the model has a good explanatory power of disclosure. The table also shows that CEO overconfidence has a high significant effect on the level of FLI disclosure at levels $(t=2.11, P>.035, t=2.46, P>.014$ and $t=8.06, P>.00)$ based on the three methods (respectively), suggesting that confident managers are risk takers (Malmendier and Tate 2005a). This result supports a positive and significant relation between the level of FLI disclosure and CEO overconfidence. A possible explanation is that, overconfident managers are likely to be more optimistic about future circumstances. Thus, confident managers are more likely to distinguish themselves from other managers through voluntary disclosures. This result is consistent with Francis et al. (2008a) and Demerjian et al. (2012), who found a positive relationship between a CEO reputation and managerial talent as proxies for overconfidence and financial reporting quality measured by the level of voluntary disclosure. In addition, this result corroborates Hribar and Yang (2010), who found a positive relationship between a CEO overconfidence and voluntary forecasts, consistent with the upper echelons theory perspective, which suggests that specific personal characteristics of top management affect the decision-making process (Hambrick 2007). A possible explanation for these findings is that overconfident managers are more likely to be more optimistic about future circumstances. Thus, the results of the three panels support H1, in agreement with the agency theory perspective. Disclosures may be a tool for managers to convince stockholders about their optimal behaviour in response to the owner's attempt to control their activities through bonding and monitoring actions (Watson et al. 2002).

The significantly positive coefficient at level $(t=2.11, P>.034, t=2.01, P>.044$, and $t=$ 2.69, $P<.007)$ of CEO gender indicates that companies managed by male CEOs are associated with more FLI disclosure than those managed by female CEOs. This finding confirms that gender diversity is one of the attributes influencing the voluntary information disclosures in annual reports (Gibbins et al. 1990; Nalikka 2009). This result supports H2, which proposes a significant relationship between the level of FLI disclosure and CEO gender, consistent with prior studies (Siciliano 1996; Erhardt et al. 2003). It might also be 
consistent with signalling theory, which posits that managers are more likely to disclose more and certain information to signal that they are better than other managers, for the purpose of enhancing their personal reputation (Campbell et al. 2001).

In respect to $\mathrm{CEO}$ age, we documented a negative significant coefficient $(t=-3.19, P<-$ $.001, t=-3.61, P<-.001$, and $t=-2.48, P<-.013)$, which implies a significant relationship between the level of FLI disclosure and CEO age. This finding is consistent with Bamber et al. (2010), who reported that older CEOs are less likely to issue forecasts than younger ones. This finding is also consistent with several studies that reported a significant negative association between CEO age and other factors, such as investment decisions (Serfling 2012; Yim 2013). The results of this study indicate that older managers tend to avoid risks more than younger managers, whereas younger managers tend to reveal their capability to stakeholders. This result is consistent with signalling theory: managers are more likely to make more FLI disclosures to the interest-related parties, to increase those parties' confidence about the company's future performance (Singhvi and Desai 1971), therefore making more FLI disclosure will provide stakeholders with greater and value-relevant information to assist them in making rational decisions (Qu et al. 2015).

This finding is also in line with suggestions that the desire to keep their position will result in a greater likelihood of information disclosure by younger CEOs (Hu and Kumar 2004), and with several studies that reported a significant negative association between the CEO age and other factors such as investment decisions (Serfling 2012; Yim 2013). The results of this study indicate that older managers tend to avoid risks more than younger managers, whereas younger managers tend to reveal their capability to the stakeholders. To sum up, the study's findings suggest that managers of non-financial Jordanian companies are more likely to pay attention to the benefits of voluntary disclosure. Since the majority of non-financial Jordanian companies are owned by family, managers of these companies might be motivated to disclose the more FLI disclosure than managers of non-family companies.

With regard to the control variables, the regression results indicate that a firm's dividend has a highly positive association with the level of FLI disclosure. This finding suggests that Jordanian companies tend to use FLI disclosure and dividend payments as alternative methods to convey important information to investors since a dividend ratio could be a sign of high performance and may attract more investors to the company. This suggests that in a developing country like Jordan, management with a high dividend ratio are more likely to 
disclose the more FLI disclosure. This finding is consistent with signalling theory, which affirms that companies are more likely to pay a higher dividend and disclose additional information voluntarily to meet the demands of financial analysts (Firth 1979; Haniffa and Cooke 2005; Celik et al. 2006; Lim et al. 2007; Kelton and Yang 2008). This finding suggests that with regard to institutional ownership, the coefficient of this variable is significant and negatively related to the level of FLI. Conversely, company size, profitability, industry type, board characteristics, managerial ownership, family ownership and blockholder ownership are found to have an insignificant influence on the level of FLI disclosure.

Regression results disprove any relationship between these variables and level of FLI disclosure. Our findings are consistent with several studies. For example, Barako et al. (2006) and Aljifri (2008) reported an insignificant relationship between the level of FLI disclosure and profitability. This seems to support the theory that profitable firms are not motivated to disclose more voluntary information because their investors are already satisfied (Wallace and Naser 1996). Our results are also consistent with previous studies in failing to provide evidence of a relationship between the level of FLI disclosure and industry type (OwusuAnsah 1998; Akhtaruddin 2005).

\section{Insert Table 4 about Regression Analysis here}

\subsection{Dealing with Endogeneity}

In order to address the endogeneity problem, this study used the lagged values of the endogenous independent variable 'CEO characteristics' as an instrumental variable (IV), to examine whether or not the simultaneity problem affects the association between FLI disclosure and CEO characteristics (Coles et al. 2008; McKnight and Weir 2009; Choi et al. 2010).

Durbin and Housman tests were run to check endogeneity bias for the endogenous and independent variables (Gujarati 2008). Both tests gave an $\mathrm{X}^{2}$ of $5.68 \%$ and $5.67 \%(P<$ $0.0172, P<0.0176$ ) respectively, which suggests that the null hypothesis (of no endogeneity between CEO characteristics as independent variable and FLI disclosure as the dependent variable) is rejected. Thus, the presence of this problem might affect the results. Therefore, instrumental variable two-stage regression was used to control for the endogeneity and simultaneity problems. 
The results of the two-stage (2SLS) regression of FLI disclosure on CEO characteristics are presented in Table 5, panels A and B. After controlling for the simultaneity, the coefficient of FLI disclosure is significant and positively related to CEO overconfidence at level $(t=4.70$, $P<.001$, and $t=2.97, P<.003$ ), which suggests that these results are consistent with the main findings in Table 4, panels A and B. The coefficient of CEO gender is significant and positively associated with the level of FLI disclosure at level $(t=6.64, P<.001$, and $t=$ 4.84, $P<.000$ ). The two-stage regression analysis shows similar results to the panel regression in Table 4. In addition, the coefficient of FLI disclosure is significant and negatively related to CEO age at levels $(t=-2.40, P<-.016$, and $t=-2.53, P<-.011)$. This result is in line with the previous results of the panel-regression random effect model reported in Table 4, panels A and B. Regarding the control variables, the results show similar results. However, although some coefficient values reveal significant high levels, the direction and significance of the association with FLI disclosure remain the same.

In summary, the instrumental variable two-stage model's results are consistent with the primary results presented in Table 4, panels A and $\mathrm{B}$, indicating that the simultaneity problem between FLI disclosure and CEO characteristics does not affect the main results of FLI disclosure or other control variables.

\section{Insert Table 5 about Instrumental Variable here}

\section{Conclusion}

The paper examined the effect of a CEO characteristics on the level of FLI disclosures in Jordanian listed companies during the period 2008 to 2013, motivated by findings reported in the literature that the financial reporting process varies predictably with particular individual characteristics of CEOs. We found that $95 \%$ of the sample were managed by male and $5 \%$ by female CEOs, and that the majority of Jordanian companies are family-owned. However, the limited number of female CEOs still surpasses the averages of around 3\% in Brazil, Botswana, Ireland, Japan, New Zealand and the UAE (Grant Thornton International Business Report, 2012). The overall results indicate that CEO overconfidence and gender have a positive and a significant association with the level of FLI disclosure. The regression further shows a significant negative association between the level of FLI disclosure and the CEO age, suggesting that older CEOs are less likely to issue forecasts than younger CEOs. This 
finding is consistent with the entrenchment theory perspective, which suggests that the desire by younger CEOs to keep their position will result in a greater likelihood of more information disclosure (Hu and Kumar 2004).

In general, the findings reveal that the main motivation for managers of Jordanian companies to disclose more FLI is to provide shareholders with greater and value-relevant information to assist them in making rational decisions. More FLI disclosure reduces information asymmetry and helps to build a good relationship with stakeholders. Furthermore, these findings indicate that managers of high quality non-financial Jordanian companies are more likely to distinguish themselves from lower quality companies through voluntary disclosures. As mentioned above, the Government of Jordan has introduced several accounting reforms with the aim of introducing new securities exchange laws and corporate disclosure practices. The findings of this study show that Jordanian companies follow these reforms and they are more likely to have a higher level of FLI disclosure compared with those of other countries. In other words, the findings indicate that Jordanian companies are more likely to improve the quality of their financial reports by extending the level of FLI disclosure. We find a positive association between the level of FLI and the dividend ratio of the company, but a negative relationship between institutional ownership and the level of FLI disclosure, and no relationship with firm characteristics such as profitability, industry type or company size, board characteristics, managerial ownership, family ownership and block holders ownership.

In the real world, a large number of companies have concerns about the possible implications of FLI disclosure on their competitive advantage, irrespective of its impact on investor understanding. This is true in countries such as Jordan, where the right to run the companies rests with managers, and FLI disclosure is generally taken with a pinch of salt. Moreover, as the financial statements do not provide the required information for investors to make economic decisions, the increasing acceptance of FLI disclosures would bring more trust among investors in the Jordanian capital market. Since there is no clearly defined structure for FLI disclosures, it is the prerogative of the company to decide on the nature of the information to be included. However, the development of good homegrown practices in FLI disclosure requires substantial educative measures at the national level on the implications of sound FLI disclosure.

The findings of the study should be of interest to policymakers, regulators and academics regarding the impact of CEO characteristics on the level of FLI disclosure not only in Jordan 
but also in other developing countries. Further, the findings of this study are likely to be of interest to investors, since this study introduces new empirical evidence about the level of FLD in Jordan. FLI disclosure is often seen as a potentially powerful tool to reflect the company's position, so these findings may have practical implications for shareholders and market members to enhance their decision making when evaluating the reliability and quality of financial reports. In addition, the findings provide empirical evidence that enables managers to assess their financial transparency and accountability, in turn helping firms to improve investors' perceptions of the quality of financial reporting. Therefore, managers should give priority to developing suitable and complete voluntary disclosures. In addition, the findings may be used by boards of directors to assess the quality of financial reporting based on the level of FLI disclosure. The findings may also help to inform regulators and policy makers about the importance of FLID in protecting investors' rights. However, these findings are based on non-financial companies only, and future studies could focus on the financial sector, which plays an increasingly important role in developing economies, particularly Jordan, which is a bridgehead of market liberalization in MENA. These results are not indicative of other countries, even within the Middle East, because of Jordan's unique liberalization and other factors. Furthermore, It would be attractive for future studies consider whether CEO's characteristics affect other disclosure contexts, such as backward-looking disclosures and the cost of voluntary disclosures. Future studies could also pay more attention to the relationship between CEO's characteristics and the level of FLI disclosure among family and non-family companies, and exploring this issue could contribute substantially to the literature of FLI disclosure. 


\section{References}

Ahmed, A. S., and S. Duellman. 2013. Managerial overconfidence and accounting conservatism. Journal of Accounting Research 51 (1):1-30.

Akhtaruddin, M. 2005. Corporate mandatory disclosure practices in Bangladesh. The Jnternational Journal of Accounting 40 (4):399-422.

Al-Akra, M., and M. J. Ali. 2012. The value relevance of corporate voluntary disclosure in the Middle-East: The case of Jordan. Journal of Accounting and Public Policy 31 (5):533-549.

Al-Akra, M., and P. Hutchinson. 2013. Family firm disclosure and accounting regulation reform in the Middle East: The case of Jordan. Research in Accounting Regulation 25 (1):101-107.

Al-Najjar, B., and S. Abed. 2014. The association between disclosure of forward-looking information and corporate governance mechanisms: Evidence from the UK before the financial crisis period. Managerial Auditing Journal 29 (7):578-595.

Ali, A., T.-Y. Chen, and S. Radhakrishnan. 2007. Corporate disclosures by family firms. Journal of Accounting and Economics 44 (1):238-286.

Alicke, M. D. 1985. Global self-evaluation as determined by the desirability and controllability of trait adjectives. Journal of Personality and Social Psychology 49 (6):1621.

Aljifri, K. 2008. Annual report disclosure in a developing country: The case of the UAE. Advances in Accounting 24 (1):93-100.

Aljifri, K., and K. Hussainey. 2007. The determinants of forward-looking information in annual reports of UAE companies. Managerial Auditing Journal 22 (9):881-894.

Aljifri, K., and H. Khasharmeh. 2006. An investigation into the suitability of the international accounting standards to the United Arab Emirates environment. International Business Review 15 (5):505-526.

Alwshah, K. A. A. M. 2009. The impact of corporate governance and ownership structure on performance and financial decisions of firms: evidence from Jordan, University of Hull.

Aribi, Z. A., and S. Gao. 2010. Corporate social responsibility disclosure: A comparison between Islamic and conventional financial institutions. Journal of Financial Reporting and Accounting 8 (2):72-91.

Arun, T. G., Y. E. Almahrog, and Z. A. Aribi. 2015. Female directors and earnings management: Evidence from UK companies. International Review of Financial Analysis 39:137-146.

ASE, A. S. E. M. Companies Control Department classification 2015 [cited.

Athanasakou, V., and K. Hussainey. 2014. The perceived credibility of forward-looking performance disclosures. Accounting and business research 44 (3):227-259.

Athanasakou, V. E., N. C. Strong, and M. Walker. 2009. Earnings management or forecast guidance to meet analyst expectations? Accounting and business research 39 (1):3-35.

Bamber, L. S., J. Jiang, and I. Y. Wang. 2010. What's my style? The influence of top managers on voluntary corporate financial disclosure. The Accounting Review 85 (4):1131-1162. 
Barako, D. G., P. Hancock, and H. Izan. 2006. Factors influencing voluntary corporate disclosure by Kenyan companies. Corporate Governance: An International Review 14 (2):107-125.

Ben-David, I., J. R. Graham, and C. R. Harvey. 2010. Managerial miscalibration: National Bureau of Economic Research.

Bertrand, M., and A. Schoar. 2002. Managing with style: The effect of managers on firm policies.

Bryan, S. H. 1997. Incremental information content of required disclosures contained in management discussion and analysis. Accounting Review:285-301.

Camerer, C., and D. Lovallo. 1999. Overconfidence and excess entry: An experimental approach. American economic review:306-318.

Campbell, D., P. Shrives, and H. Bohmbach-Saager. 2001. Voluntary disclosure of mission statements in corporate annual reports: signaling what and to whom? Business and society review 106 (1):65-87.

Campbell, J. Y. 2001. Forecasting US equity returns in the 21st century. Estimating the real rate of return on stocks over the long term, August:3-10.

Campbell, T. C., M. Gallmeyer, S. A. Johnson, J. Rutherford, and B. W. Stanley. 2011. CEO optimism and forced turnover. Journal of Financial Economics 101 (3):695-712.

Celik, O., A. Ecer, and H. Karabacak. 2006. Disclosure of forward looking information: Evidence from listed companies on Istanbul Stock Exchange (ISE). Investment Management and Financial Innovations 3 (2):197-216.

Cerf, A. R. 1961. Corporate reporting and investment decisions: Public Accounting Research Program, Institute of Business and Economic Research, University of California.

Chau, G., and S. J. Gray. 2010. Family ownership, board independence and voluntary disclosure: Evidence from Hong Kong. Journal of International Accounting, Auditing and Taxation 19 (2):93-109.

Choi, J.-S., Y.-M. Kwak, and C. Choe. 2010. Corporate social responsibility and corporate financial performance: Evidence from Korea. Australian Journal of Management 35 (3):291-311.

Clarkson, P. M., Y. Li, G. D. Richardson, and F. P. Vasvari. 2008. Revisiting the relation between environmental performance and environmental disclosure: An empirical analysis. Accounting, Organizations and Society 33 (4):303-327.

Coles, J. L., N. D. Daniel, and L. Naveen. 2008. Boards: Does one size fit all? Journal of Financial Economics 87 (2):329-356.

Cornett, M. M., J. J. McNutt, and H. Tehranian. 2009. Corporate governance and earnings management at large US bank holding companies. Journal of Corporate finance 15 (4):412-430.

Davidson, R., A. Dey, and A. Smith. 2013. Executives'“'off-the-job” behavior, corporate culture, and financial reporting risk. Journal of Financial Economics.

Dejong, D., and Z. Ling. 2013. Managers: Their effects on accruals and firm policies. Journal of Business Finance \& Accounting 40 (1-2):82-114.

Demerjian, P. R., B. Lev, M. F. Lewis, and S. E. McVay. 2012. Managerial ability and earnings quality. The Accounting Review 88 (2):463-498. 
Dowling, M., and Z. A. Aribi. 2013. Female directors and UK company acquisitiveness. International Review of Financial Analysis 29:79-86.

Erhardt, N. L., J. D. Werbel, and C. B. Shrader. 2003. Board of director diversity and firm financial performance. Corporate Governance: An International Review 11 (2):102111.

Fairchild's, R. J. 2005. The effect of Managerial Overconfidence, asymmetric information, and moral hazard on capital structure decisions. Available at SSRN 711845.

Firth, M. 1979. The impact of size, stock market listing, and auditors on voluntary disclosure in corporate annual reports. Accounting and business research 9 (36):273-280.

Francis, J., A. H. Huang, S. Rajgopal, and A. Y. Zang. 2008a. CEO Reputation and Earnings Quality. Contemporary accounting research 25 (1):109-147.

Francis, J., D. Nanda, and P. Olsson. 2008b. Voluntary disclosure, earnings quality, and cost of capital. Journal of Accounting Research 46 (1):53-99.

Ge, W., D. Matsumoto, and J. L. Zhang. 2011. Do CFOs Have Style? An Empirical Investigation of the Effect of Individual CFOs on Accounting Practices*. Contemporary accounting research 28 (4):1141-1179.

Gibbins, M., A. Richardson, and J. Waterhouse. 1990. The management of corporate financial disclosure: opportunism, ritualism, policies, and processes. Journal of Accounting Research:121-143.

Gujarati, D. 2008. N, 2003, Basic Econometrics,“: International Edition, Mcgraw-Hill.

Gul, F., M. Hutchinson, and K. Lai. 2011. Gender diversity and properties of analysts forecast: Working paper. Monash University, Sunway, Malaysia.

Hackbarth, D. 2008. Managerial traits and capital structure decisions. Journal of Financial and Quantitative Analysis 43 (04):843-881.

Hackston, D., and M. J. Milne. 1996. Some determinants of social and environmental disclosures in New Zealand companies. Accounting, Auditing \& Accountability Journal 9 (1):77-108.

Hambrick, D. C. 2007. Upper echelons theory: An update. Academy of management Review $32(2): 334-343$.

Haniffa, R., and T. E. Cooke. 2005. The impact of culture and governance on corporate social reporting. Journal of Accounting and Public Policy 24 (5):391-430.

Hassanein, A., and K. Hussainey. 2015. Is forward-looking financial disclosure really informative? Evidence from UK narrative statements. International Review of Financial Analysis 41:52-61.

Hirshleifer, D., A. Low, and S. H. Teoh. 2012. Are overconfident CEOs better innovators? The journal of finance 67 (4):1457-1498.

Ho, S. S., A. Y. Li, K. Tam, and F. Zhang. 2015. CEO Gender, Ethical Leadership, and Accounting Conservatism. Journal of Business Ethics 127 (2):351-370.

Hribar, P., and H. Yang. 2010. Does CEO overconfidence affect management forecasting and subsequent earnings management. Unpublished working paper.

Hribar, P., and H. 2015. CEO overconfidence and management forecasting. Contemporary accounting research.

$\mathrm{Hu}$, A., and P. Kumar. 2004. Managerial entrenchment and payout policy. Journal of Financial and Quantitative Analysis 39 (04):759-790. 
Hussainey, K., T. Schleicher, and M. Walker. 2003. Undertaking large-scale disclosure studies when AIMR-FAF ratings are not available: the case of prices leading earnings. Accounting and business research 33 (4):275-294.

Hussainey, K., and M. Walker. 2009. The effects of voluntary disclosure and dividend propensity on prices leading earnings. Accounting and business research 39 (1):3755.

Jensen, M. C., and W. H. Meckling. 1976. Theory of the firm: Managerial behavior, Agency costs and ownership structure. Journal of Financial Economics 3 (4):305-360.

Jia, Y., L. V. LENT, and Y. Zeng. 2014. Masculinity, testosterone, and financial misreporting. Journal of Accounting Research 52 (5):1195-1246.

JSC, J. S. C. 2015. General Information 2015 [cited 2-12 2015].

Kelton, A. S., and Y.-w. Yang. 2008. The impact of corporate governance on Internet financial reporting. Journal of Accounting and Public Policy 27 (1):62-87.

Krishnan, G. V., and L. M. Parsons. 2008. Getting to the bottom line: An exploration of gender and earnings quality. Journal of Business Ethics 78 (1-2):65-76.

Langer, E. J. 1975. The illusion of control. Journal of Personality and Social Psychology 32 (2):311.

Li, S., D. D. Selover, and M. Stein. 2011. "Keep silent and make money": Institutional patterns of earnings management in China. Journal of Asian Economics 22 (5):369382.

Libby, R., and K. Rennekamp. 2012. Self-Serving Attribution Bias, Overconfidence, and the Issuance of Management Forecasts. Journal of Accounting Research 50 (1):197-231.

Lim, S., Z. Matolcsy, and D. Chow. 2007. The association between board composition and different types of voluntary disclosure. European Accounting Review 16 (3):555-583.

Lin, Y. C., Y. C. Wang, J. R. Chiou, and H. W. Huang. 2014. CEO Characteristics and Internal Control Quality. Corporate Governance: An International Review 22 (1):2442.

Maali, B., P. Casson, and C. Napier. 2006. Social reporting by Islamic banks. Abacus 42 (2):266-289.

Malmendier, U., and G. Tate. 2005a. CEO overconfidence and corporate investment. The journal of finance 60 (6):2661-2700.

Malmendier, U., and G. Tate. 2008. Who makes acquisitions? CEO overconfidence and the market's reaction. Journal of Financial Economics 89 (1):20-43.

Malmendier, U., G. Tate, and J. Yan. 2007. Corporate financial policies with overconfident managers: National Bureau of Economic Research.

Mathuva, D. 2012. The Determinants of Forward-looking Disclosures in Interim Reports for Non-financial Firms: Evidence from a Developing Country. International Journal of Accounting and Financial Reporting 2 (2):Pages 125-141.

McKnight, P. J., and C. Weir. 2009. Agency costs, corporate governance mechanisms and ownership structure in large UK publicly quoted companies: A panel data analysis. The Quarterly Review of Economics and Finance 49 (2):139-158.

Menicucci, E. 2013. Firms characteristics and forward-looking information in management commentaries of Italian listed companies. African Journal of Business Management 7 (17):1667-1674. 
Miller, D., and J. Shamsie. 2001. Learning across the life cycle: Experimentation and performance among the Hollywood studio heads. Strategic Management Journal 22 (8):725-745.

Minggui, Y., X. Xinping, and Z. Zhensong. 2006. The relationship between managers' overconfidence and enterprises' radical behavior in incurring debts. Management world 8:358-379.

Nalikka, A. 2009. Impact of Gender Diversity on Voluntary Disclosure in Annual Reports. Accounting \& Taxation 1 (1):101-113.

Ng, L. 1985. Social responsibility disclosures of selected New Zealand companies for 1981, 1982 and 1983, occasional paper,(vol. 54). Palmerston North: Massey University.

O’Sullivan, M., M. Percy, and J. Stewart. 2008. Australian evidence on corporate governance attributes and their association with forward-looking information in the annual report. Journal of Management \& Governance 12 (1):5-35.

Oliver, B. R., and S. Mefteh. 2010. Capital structure choice: the influence of sentiment in France. International Journal of Behavioural Accounting and Finance 1 (4):294-311.

Omar, B. F. A. 2007. Exploring the aggregate, mandatory and voluntary financial disclosure behaviour under a new regulatory environment: the case of Jordan, University of Hull.

Owusu-Ansah, S. 1998. The impact of corporate attribites on the extent of mandatory disclosure and reporting by listed companies in Zimbabwe. The International Journal of Accounting 33 (5):605-631.

Peasnell, K. V., P. F. Pope, and S. Young. 2005. Board monitoring and earnings management: do outside directors influence abnormal accruals? Journal of Business Finance \& Accounting 32 (7-8):1311-1346.

Peterson, C. A., and J. Philpot. 2007. Women's roles on US Fortune 500 boards: Director expertise and committee memberships. Journal of Business Ethics 72 (2):177-196.

Qu, W., M. S. Ee, L. Liu, V. Wise, and P. Carey. 2015. Corporate governance and quality of forward-looking information: Evidence from the Chinese stock market. Asian Review of Accounting 23 (1):39-67.

Rizk, R., R. Dixon, and A. Woodhead. 2008. Corporate social and environmental reporting: a survey of disclosure practices in Egypt. Social Responsibility Journal 4 (3):306-323.

Saadi-Sedik, T., and M. Petri. 2006. To Smooth or Not to Smooth-The Impact of Grants and Remittances on the Equilibrium Real Exchange Rate in Jordan: International Monetary Fund.

Salama, A., N. Sun, K. Hussainey, and M. Habbash. 2010. Corporate environmental disclosure, corporate governance and earnings management. Managerial Auditing Journal 25 (7):679-700.

Samaha, K., K. Dahawy, K. Hussainey, and P. Stapleton. 2012. The extent of corporate governance disclosure and its determinants in a developing market: The case of Egypt. Advances in Accounting 28 (1):168-178.

Sartawi, I. I. M., R. M. Hindawi, R. Bsoul, and A. e. J. Ali. 2014. Board Composition, Firm Characteristics, and Voluntary Disclosure: The Case of Jordanian Firms Listed on the Amman Stock Exchange. International Business Research 7 (6):p67.

Schleicher, T., K. Hussainey, and M. Walker. 2007. Loss firms' annual report narratives and share price anticipation of earnings. The British Accounting Review 39 (2):153-171. 
Schleicher, T., and M. Walker. 2010. Bias in the tone of forward-looking narratives. Accounting and business research 40 (4):371-390.

Schrand, C. M., and S. L. Zechman. 2012. Executive overconfidence and the slippery slope to financial misreporting. Journal of Accounting and Economics 53 (1):311-329.

Serfling, M. A. 2012. CEO age, underinvestment, and agency costs. Eller College of Management, University of Arizona.

Siciliano, J. I. 1996. The relationship of board member diversity to organizational performance. Journal of Business Ethics 15 (12):1313-1320.

Singhvi, S. S., and H. B. Desai. 1971. An empirical analysis of the quality of corporate financial disclosure. Accounting review:129-138.

Skala, D. 2008. Overconfidence in psychology and finance-an interdisciplinary literature review. Bank i Kredyt (4):33-50.

Skalpe, O. 2007. The CEO gender pay gap in the tourism industry-Evidence from Norway. Tourism Management 28 (3):845-853.

Taylor, R. N. 1975. Age and experience as determinants of managerial information processing and decision making performance. Academy of Management journal 18 (1):74-81.

Wallace, R., and K. Naser. 1996. Firm-specific determinants of the comprehensiveness of mandatory disclosure in the corporate annual reports of firms listed on the stock exchange of Hong Kong. Journal of Accounting and Public Policy 14 (4):311-368.

Wang, M., and K. Hussainey. 2013. Voluntary forward-looking statements driven by corporate governance and their value relevance. Journal of Accounting and Public Policy 32 (3):26-49.

Watson, A., P. Shrives, and C. Marston. 2002. Voluntary disclosure of accounting ratios in the UK. The British Accounting Review 34 (4):289-313.

Watts, R. L., and J. L. Zimmerman. 1978. Towards a positive theory of the determination of accounting standards. Accounting review:112-134.

Yim, S. 2013. The acquisitiveness of youth: CEO age and acquisition behavior. Journal of Financial Economics 108 (1):250-273.

Yu, S., R. Lord, E. Peni, and S. Vähämaa. 2010. Female executives and earnings management. Managerial Finance 36 (7):629-645. 


\section{Appendix 1: Compliance with the Economic Cooperation and Development (OECD)} Principles: Jordan and the World

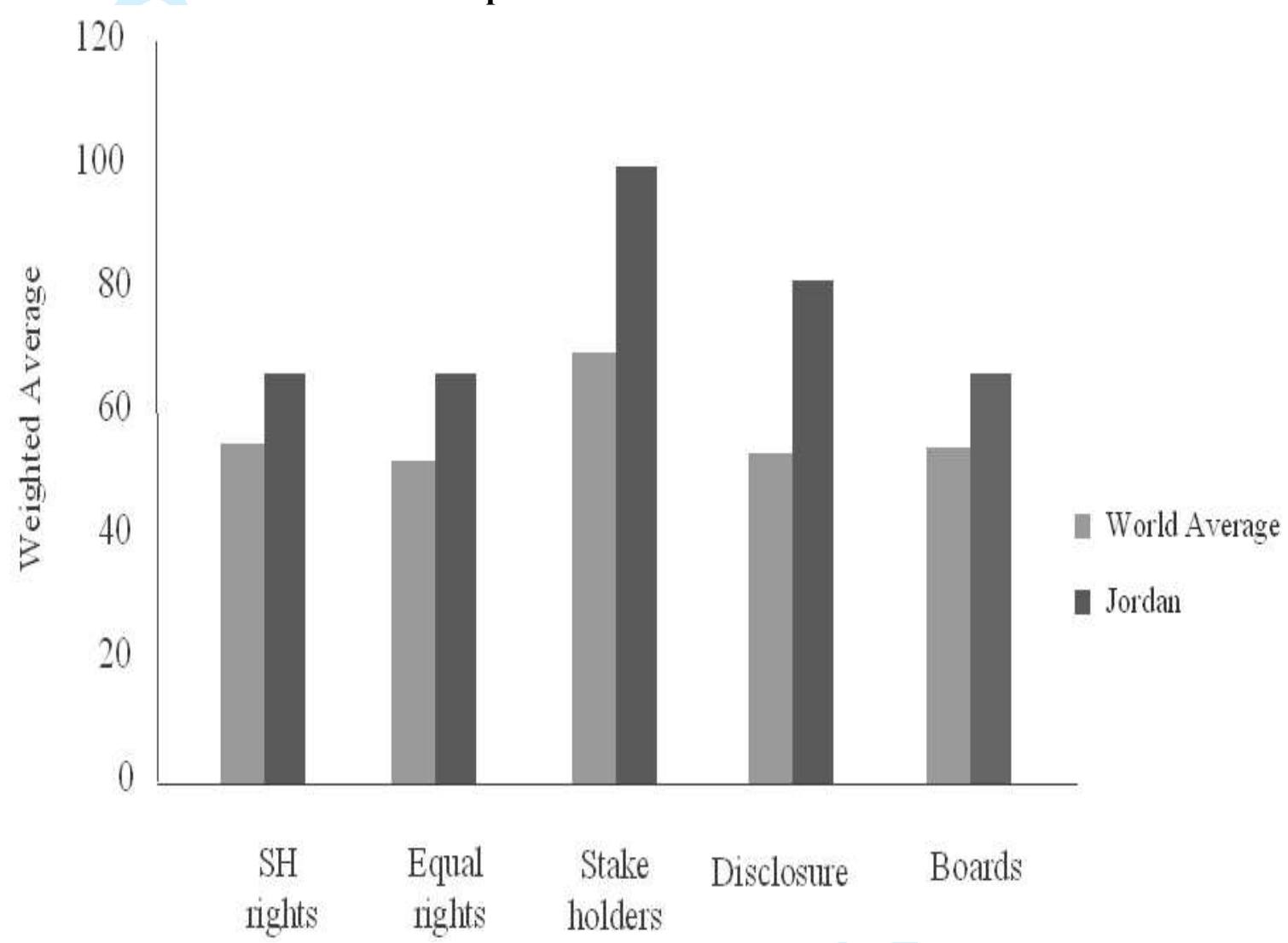

Source: Alwshah (2009, P. 22). 
Appendix 2: List of 35 Forward-Looking Key Words

Number Forward-Looking Key words

1 Accelerate

2 Anticipate

3 Await

$4 \quad$ Coming financial year(s)

5 Coming months

6 Confidence (or confident)

7 Convince

8 Current financial year

$9 \quad$ Envisage

10 Estimate

11 Eventual

12 Expect

13 Forecast

14 Forthcoming

15 Hope

16 Intend (or intention)

17 Likely (or unlikely)

18 Look forward (or look ahead)

19 Next

20 Novel

$21 \quad$ Optimistic

22 Outlook

23 Planned (or planning)

$24 \quad$ Predict

$25 \quad$ Prospect

26 Remain

27 Renew

28 Scope for (or scope to)

29 Shall

30 Shortly

31 Should

32 Soon

33 Will

$34 \quad$ Well placed (or well positioned)

$35 \quad$ Year(s) ahead

Source: (Hussainey et al. 2003, P. 277). 
Appendix 3: FLI disclosure Categories and Items

\section{Financial FLI items}

- Income

- Profit

- Loss

- Cash flow

- Capital

- Return on equity

- Sales

- Capital expenditures

- Production

- Cost

- Expenses

$>$ Non-Financial FLI items Strategies items:

- Goals for performance

- Mission

- Objectives

$>$ Company structure

- Financial structure

- Change in ownership

- Industry type

- Human and intellectual capital

- Mergers and acquisitions

- Technological structure

$>$ Environment

- Legal and regulatory

- Political

- Economic conditions

- Social responsibility

- Competitive position

- Financial and non-financial resources

- Risks

- Relationship

Source: Authors' development 
Table 1

Sample Description

\begin{tabular}{|c|c|c|c|c|c|c|c|}
\hline Description & 2008 & 2009 & 2010 & 2011 & 2012 & 2013 & Pooled \\
\hline Initial sample & 270 & 270 & 270 & 270 & 270 & 270 & 1620 \\
\hline \multicolumn{8}{|l|}{ Excluded: } \\
\hline Financial industries & 42 & 42 & 42 & 42 & 42 & 42 & (252) \\
\hline Non-financial industries & 228 & 228 & 228 & 228 & 228 & 228 & 1326 \\
\hline \multicolumn{8}{|l|}{ Industries with fewer than six firms } \\
\hline Health care & 4 & 4 & 4 & 4 & 4 & 4 & 24 \\
\hline Technology and communication & 1 & 1 & 1 & 1 & 1 & 1 & 6 \\
\hline Media & 2 & 2 & 2 & 2 & 2 & 2 & 12 \\
\hline Paper and cardboard & 3 & 3 & 3 & 3 & 3 & 3 & 18 \\
\hline Utilities and energy & 3 & 3 & 3 & 3 & 3 & 3 & 18 \\
\hline Printing and packaging & 1 & 1 & 1 & 1 & 1 & 1 & 6 \\
\hline Tobacco and cigarettes & 2 & 2 & 2 & 2 & 2 & 2 & 12 \\
\hline \multirow[t]{2}{*}{ Glass and ceramic industries } & 1 & 1 & 1 & 1 & 1 & 1 & 6 \\
\hline & & & & & & & $(102)$ \\
\hline Firms with unavailable data & 10 & 10 & 10 & 10 & 10 & 10 & $(60)$ \\
\hline Final sample & 201 & 201 & 201 & 201 & 201 & 201 & 1206 \\
\hline
\end{tabular}

Table 2

Descriptive Statistics: Dependent and Independent Variables

\begin{tabular}{lcccccc}
\hline Variables & $\mathrm{N}$ & Minimum & Maximum & Mean & Median & Std. Deviation \\
\hline FLI & 1206 & .00 & .78 & .316 & .330 & .149 \\
COVER & 1206 & 0 & 1 & .430 & .000 & .499 \\
CAPEX & 1206 & 0 & 1 & .497 & 1 & .410 \\
LEVER & 1206 & .0020 & .977 & .294 & .240 & .233 \\
CGEN & 1206 & 0 & 1 & .952 & 1 & .170 \\
CAGE & 1206 & 26 & 84 & 51.1 & 51.0 & 11.3 \\
FSIZE1 & 1206 & .93 & 3.23 & 5.55 & 1.87 & 1.57 \\
FPROF & 1206 & -.859 & .950 & -.001 & .009 & .125 \\
FINDU & 1206 & 1 & 20 & .363 & .240 & .481 \\
FDIVID & 1206 & 0 & .975 & .176 & 0 & .299 \\
BSIZE & 1206 & 3 & 19 & 8.01 & 7 & 2.449 \\
BDUAL & 1206 & 0 & 1 & .205 & 0 & .404 \\
BMEET & 1206 & 3 & 28 & 7.572 & 7 & 2.137 \\
BINDEP & 1206 & 0 & 8 & 2.020 & 2 & 1.234 \\
MOWNE & 1206 & 0 & .718 & .035 & 0 & .085 \\
FOWNE & 1206 & 0 & .945 & 0.612 & .1547 & .272 \\
INSTIT & 1206 & 0 & 1 & .355 & .332 & .765 \\
BLOCK & 1206 & 0 & 1 & .489 & 0 & .500 \\
Valid N & 1206 & & & & & \\
\hline
\end{tabular}

\footnotetext{
${ }^{1}$ Following previous studies company's size is measured by using the natural logarithm of total assets at the year-end (Aljifri and Hussainey 2007; Samaha et al. 2012; Wang and Hussainey 2013).
} 
Table 3

Correlation Matrix

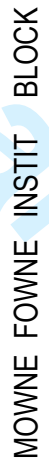

$\stackrel{8}{+}$

@: :

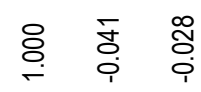

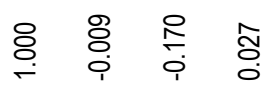

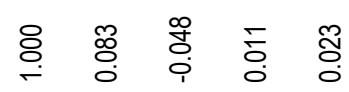

ஓ

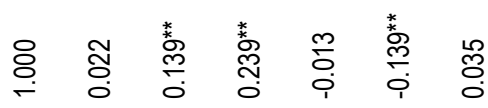

용 蔗

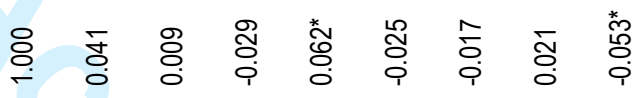

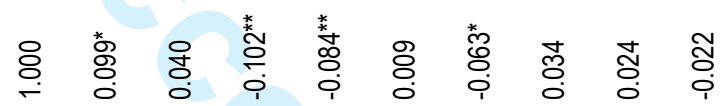

务

$\frac{w}{\mathbb{N}}$

용

岗

官

悡

官 客

邑

茴

离

品

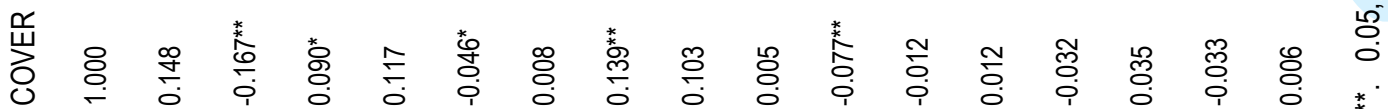

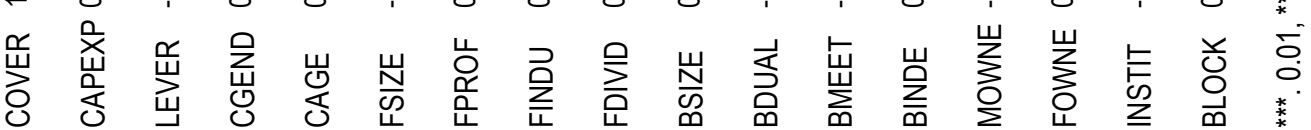


Table 4

Panel A. CEO Overconfidence Measured by 'Net Buyer'

\begin{tabular}{lllll}
\hline Variables & Expected sign & Coefficient. & $t$ & Prob. \\
\hline COVER & + & .023 & 2.11 & $0.035^{* *}$ \\
CGEN & + & .061 & 2.11 & $0.034^{* *}$ \\
CAGE & - & -.001 & -3.19 & $-0.001^{* * *}$ \\
FSIZE & + & 3.43 & 0.82 & 0.411 \\
FPROF & + & .032 & 0.70 & 0.485 \\
FINDU & $?$ & .006 & 0.07 & 0.918 \\
FDIVID & $?$ & .058 & 3.14 & $0.002^{* * *}$ \\
BSIZE & $?$ & -.003 & -0.88 & 0.377 \\
BDUAL & + & .008 & 0.44 & 0.659 \\
BMEET & $?$ & .001 & 0.50 & 0.618 \\
BINDEP & - & .007 & 1014 & .0252 \\
MOWNE & + & .052 & 0.67 & 0.501 \\
FOWNE & $?$ & -.000 & -0.13 & 0.895 \\
INSTIT & $?$ & -.059 & -2.33 & $0.020^{* *}$ \\
BLOCK & - & -.005 & -0.41 & 0.683 \\
Cons & & .349 & 4.74 & $0.000^{* * *}$ \\
R Sq. value & $25.69 \%$ & & & \\
P. value & 0.000 & & &
\end{tabular}


Panel B. CEO Overconfidence Measured by Capital Expenditure

\begin{tabular}{|c|c|c|c|c|}
\hline Variables & Expected sign & Coefficient. & $t$ & Prob. \\
\hline COVER & + & .028 & 2.46 & $0.014^{* *}$ \\
\hline CGEN & + & .058 & 2.01 & $0.044^{* *}$ \\
\hline CAGE & - & -.002 & -3.61 & $0.001^{* * *}$ \\
\hline FSIZE & + & 4.56 & 1.08 & 0.278 \\
\hline FPROF & + & .027 & 0.58 & 0.559 \\
\hline $\begin{array}{l}\text { FINDU } \\
\text { FDIVID }\end{array}$ & $\begin{array}{l}? \\
?\end{array}$ & $\begin{array}{l}-3.27 \\
.065\end{array}$ & $\begin{array}{l}-0.23 \\
3.52\end{array}$ & $\begin{array}{l}0.817 \\
0.001^{\text {*** }}\end{array}$ \\
\hline BSIZE & $?$ & -.003 & -1.04 & 0.300 \\
\hline BDUAL & + & .002 & 0.09 & 0.925 \\
\hline BMEET & $?$ & .001 & 0.39 & 0.693 \\
\hline BINDEP & - & .008 & 1.26 & 0.209 \\
\hline MOWNE & + & -.048 & 0.62 & 0.538 \\
\hline FOWNE & $?$ & -.000 & -0.08 & 0.932 \\
\hline INSTIT & $?$ & -.059 & -2.42 & $0.019^{\star * *}$ \\
\hline BLOCK & - & -.005 & -0.38 & 0.701 \\
\hline Cons & & .353 & 9.31 & $0.001^{* * *}$ \\
\hline
\end{tabular}

R Sq. value $\quad 38.30 \%$

$P$. value $\quad 0.001$

\begin{tabular}{lllll}
\hline & \multicolumn{4}{l}{ Panel C. CEO Overconfidence Measured by Leverage } \\
\hline Variables & Expected sign & Coefficient. & $t$ & Prob. \\
\hline COVER & + & .192 & 8.06 & $0.000^{* * *}$ \\
CGEN & + & .042 & 2.69 & $0.007^{* * *}$ \\
CAGE & - & -.001 & -2.48 & $0.013^{* * *}$ \\
FSIZE & + & 2.78 & 0.68 & 0.494 \\
FPROF & + & .086 & 1.90 & $0.058^{* *}$ \\
FINDU & $?$ & 9.16 & 0.07 & 0.946 \\
FDIVID & $?$ & .050 & 2.78 & $0.005^{* * *}$ \\
BSIZE & $?$ & -.003 & -0.95 & 0.343 \\
BDUAL & + & .008 & 0.48 & 0.633 \\
BMEET & $?$ & .002 & 0.59 & 0.556 \\
BINDEP & - & .004 & 0.71 & 0.478 \\
MOWNE & + & .042 & 0.56 & 0.578 \\
FOWNE & $?$ & .000 & 0.30 & 0.767 \\
INSTIT & $?$ & -.048 & -1.95 & $0.052^{* *}$ \\
BLOCK & - & -.025 & -1.82 & $0.069^{*}$ \\
Cons & & .306 & 8.15 & $0.000^{* * *}$
\end{tabular}

R Sq. value $\quad 23.45 \%$

P. value $\quad 0.000$ 
Table 5

Panel A. Instrumental Variable: CEO Overconfidence Measured by 'Net Buyer'

\begin{tabular}{lllll}
\hline Variables & Expected sign & Coefficient. & $t$ & Prob. \\
\hline LCOVER & + & .106 & 4.70 & $0.001^{* * *}$ \\
LCGEN & + & .302 & 6.64 & $0.001^{* * *}$ \\
LCAGE & - & -.003 & -2.40 & $0.016^{* *}$ \\
FSIZE & + & 2.37 & 6.51 & $0.001^{* * *}$ \\
FPROF & + & -.067 & -1.64 & $0.101^{*}$ \\
FINDU & $?$ & 6.92 & 0.82 & 0.413 \\
FDIVID & $?$ & .073 & 4.30 & $0.000^{* * *}$ \\
BSIZE & $?$ & .004 & 1.99 & $0.047^{* *}$ \\
BDUAL & + & .014 & 1018 & 0.237 \\
BMEET & $?$ & -.001 & -0.55 & 0.584 \\
BINDEP & - & .005 & 1.33 & 0.183 \\
MOWNE & + & -.059 & -1.07 & 0.285 \\
FOWNE & $?$ & -.048 & -2.51 & $0.012^{\star *}$ \\
INSTIT & $?$ & -.047 & -2.76 & $0.006^{* * *}$ \\
BLOCK & - & -.001 & -0.09 & 0.929 \\
Cons & & .286 & 11.13 & $0.000^{* * *}$ \\
R Sq. value & $78 \%$ & & & \\
P. value & 0.000 & & &
\end{tabular}

Panel B. CEO Overconfidence Measured by Capital Expenditure

\begin{tabular}{lllll}
\hline Variables & Expected sign & Coefficient. & $t$ & Prob. \\
\hline LCOVER & + & .155 & 2.97 & $0.003^{* * *}$ \\
LCGEN & + & .229 & 4.84 & $0.000^{* * *}$ \\
LCAGE & - & -.003 & -2.53 & $0.011^{* * *}$ \\
FSIZE & + & 2.32 & 5.91 & $0.000^{* * *}$ \\
FPROF & + & .162 & 2.32 & $0.020^{* *}$ \\
FINDU & $?$ & 6.92 & 0.84 & 0.400 \\
FDIVID & $?$ & .074 & 4.08 & $0.000^{* * *}$ \\
BSIZE & $?$ & .005 & 2.34 & $0.020^{* * *}$ \\
BDUAL & + & .019 & 1.46 & 0.145 \\
BMEET & $?$ & -.002 & -0.93 & 0.351 \\
BINDEP & - & .003 & 0.73 & 0.467 \\
MOWNE & + & -.074 & -1.65 & 0.210 \\
FOWNE & $?$ & -.073 & -3.55 & $0.000^{* * *}$ \\
INSTIT & $?$ & -.045 & -2.47 & $0.014^{* * *}$ \\
BLOCK & - & .007 & 0.69 & 0.492 \\
Cons & & .275 & 9.91 & $0.000^{* * *}$ \\
R Sq. value & $75.50 \%$ & & & \\
P. value & 0.000 & & &
\end{tabular}

